\title{
Effectiveness of Financing and Means Management on Educational Quality in Private Aliyah Madrasah Yapena Lhokseumawe City
}

\author{
Cut Zahri Harun ${ }^{1}$, Khairuddin ${ }^{2}$ and Niswanto ${ }^{3}$ \\ ${ }^{1,2,3}$ Syiah Kuala University, Banda Aceh, Indonesia \\ \{1profcut@unsyiah.ac.id\}
}

\begin{abstract}
Education funding is an important factor in the operational improvement of education quality. The study aims to determine the process of preparing education financing plans, implementation of education cost plans, and accountability for education funding in an effort to improve the quality of education at YAPENA High School in Lhokseumawe City. The study was conducted using the descriptive method with a qualitative approach. Data collection techniques with interviews and documentation studies. The subjects of the research data were the Head, Deputy Head of SMA (4 people), School Committee (3 people), YAPENA Foundation Management (3 people), and parents/guardians of students (3 people). The results of the study were, first, the preparation of the YAPENA High School financing plan was carried out routinely at the beginning of the year through a special meeting to prepare a funding plan for YAPENA High School education, and carried out before the school year began. The parties included the Principal, deputy headmaster, School Committee, Parents / Guardians of students, and YAPENA High School Foundation. The results of meeting decisions are documented to be used as guidelines in the financing plan finalization. Second, the implementation of the financing plan always uses plans that have been compiled. If there is an urgent matter so that it has to change the financing plan when the school year is running, then it must go through a meeting attended by parties who are involved in preparing the financing plan. In this meeting explained the reasons for changes in financing plans while still prioritizing the achievement of education quality. Third, accountability for the use of education costs is carried out transparently, so that the parties who participate in preparing the education financing plan can clearly see the flow of education costs and the quality of education.
\end{abstract}

Keywords: Financing, Facilities, Quality of Education

\section{Introduction}

\subsection{Background}

The reforms which began in 1998 resulted in a number of demands, including the regional autonomy stipulated in Law No.22 of 1999. As a further consequence of the law, Law No. 25 of 1999 concerning Central and Regional Financial Balance was also stipulated. The enactment of this law resulted in changes in the authority and freedom of the Regional Government in 
managing the Government in the regions, except foreign policy, defense, justice, monetary and fiscal, religion, and the fields established by government regulations.

Regional Autonomy which has been officially implemented since 2001 also brings changes in the management of education, from centralistic to decentralized. The shift in education management from centralistic to decentralized raises a number of challenges in its implementation, such as the management of human resources, educational facilities and infrastructure, and ensuring the availability of the education budget needed through community participation.

In line with the development of education management, the term school-based management (MBS) emerged, with the aim of establishing schools in the management of education, both in terms of implementation, development, supervision, and financing of education. The essence of SBM implementation is to improve the efficiency, relevance, equity and quality of education, and to fulfill the principles of justice and democratization of education management. In SBM schools are required to have the ability to plan, implement, and evaluate and account for the management of education costs in a transparent manner.

SBM is not only applied in schools under the Ministry of Education and Culture, schools (Madrasah) managed by the Ministry of Religion, both state and private, also apply SBM. Based on this background, the authors are interested in conducting research on the Effectiveness of the Management of Financing and Education Facilities on the Quality of Education in Yapena Private Madrasas in Lhokseumawe City.

\subsection{Formulation of the problem}

The problems in this study are as follows:

1. How to manage education costs in Yapena Private Madrasah in Lhokseumawe City.

2. How is the effectiveness of cost management to improve the quality of education in Yapena Private Madrasah in Lhokseumawe City.

3. What factors are obstacles to the management of education costs in Yapena Private Madrasah in Lhokseumawe City.

\subsection{Research purposes}

Based on the problems that have been determined, the purpose of this research is to find out:

1. Management of education costs in Yapena Private Madrasah in Lhokseumawe city.

2. The effectiveness of managing costs and means to improve the quality of education in Yapena Private Madrasas in Lhokseumawe city.

3. Obstacles in managing education costs in Yapena Private Madrasah in Lhokseumawe city

\subsection{Benefits of research}

The results of this study are expected to provide the following theoretical and practical benefits:

1. Can contribute ideas in the management of educational institutions, especially the management of education costs in schools.

2. Can be used as a material consideration for schools in determining policies for managing education costs and facilities to be more effective.

3. For researchers, can add insight and knowledge in managing education costs.

4. For readers, this research can inspire further research related to the management of education costs. 


\section{Literature Review}

\subsection{Concept of Education Financing}

Education financing basically is a process of allocating resources to activities or programs for implementing operational education, both directly and indirectly. Speaking of costs, there are three main things, namely: funding sources, use (allocation), and remaining budget.

Simple financing management can be interpreted as a process of carrying out activities to mobilize others, taking into account aspects of effectiveness and efficiency relating to acquisition (source), use (allocation), with a comprehensive goal starting from planning, organizing, implementing, supervising, and accountability.

Minarti [1] argues that: In general, management or management system of an educational institution including pesantren education must pay attention to several components, namely: curriculum management, student management, facilities and infrastructure management, public relations management, personnel management, and most importantly management finance. Financing management is one of the important components regarding all activities related to funding sources and management of activities with several overall objectives.

Marno \& Supriyatno [2] provide a definition of financial management as the management of financial functions, namely the function of how the management is able to raise of funds and allocate (funds of funds) these funds so that the goals of educational organizations are achieved effectively and efficiently.

Simple financing management can be interpreted as a process of carrying out activities by mobilizing others, taking into account the effectiveness and efficiency aspects relating to acquisition, funding, with overall objectives starting from planning, organizing, implementing, supervising. Likewise, the management of education facilities and infrastructures of the pesantren starts from budget planning to supervision and accountability.

Education financing is also a process whereby available income and resources are used to formulate and operationalize educational institutions with regard to education and government financing programs and school administration. There are several factors that determine the financing of education including the size of an educational institution, the small number of students and teachers and the good or lack of facilities and infrastructure.

In connection with the above problems, Fattah [3] said that: Education funding is determined by various factors, namely: the size of a school, the number of students, the level of honorarium for teachers and lecturers in accordance with their respective fields of expertise or level of education, student ratios and teaching staff, teacher qualifications, population growth rates for developing countries and changes in payroll or income policies.

Correspondingly, Suhardan, Riduwan, \& Enas [4] suggested that: "Education financing is intended for the implementation of learning activities in achieving the noble work ethic of the nation which is stated in the purpose of education. This goal is philosophical, broad, comprehensive, and fundamental in realizing the goal noble nation ".

In Law Number 20 of 2003 concerning the National Education System, it is stipulated that: Educational resources are a supporter and supporter of the implementation of education which includes education personnel, funds, facilities and infrastructure available or held and utilized by families, communities, students and the government, both stand-alone and together. In another article, it is stated that the availability and utilization of educational resources are carried out by the government, the community and the families of students. Whereas the financing of the implementation of educational activities in educational units organized by the government 
is the responsibility of the government and those held by the community are the responsibility of the agency or individual who carries out the education.

The results of Jafar, AR, \& Khairuddin[5] research conducted at the Nurul Islamic Boarding School in one of the sub-districts in Bireuen District showed that the financial management of pesantren was carried out by a wadir assisted by several staff and accountable to the pesantren leadership. which is mature, implementation and supervision until accountability is carried out accountably, considering that financial problems are a risky issue in public talks.

From the explanation above, the management of education funding is an important component that must be an in-depth study concerning the implementation of education in educational institutions in Aceh, especially pesantren education institutions in order to realize the vision and mission objectives and institutions that have been set in achieving education objectives according in the hope of the government and the people of Aceh.

Education financing is all the processes and ways to obtain financing (input) and expenditure (output). In connection with this problem, [6] stated that: Education financing is all types of activities in the delivery of education concerning efforts to find resources and those that will be used effectively in the administration of education. In line with this, Suryosubroto [7] also said that: Education financing is an activity to obtain financing managed for the expenditure of an educational institution, starting from planning financing activities, finding funding sources for planned activities, use, and supervision of the use of these costs.

Moreover, education is indeed the mandate of the 1945 Constitution, namely "every citizen has the right to education". Therefore, the Indonesian Government has budgeted or allocated a budget for education by $20 \%$ of the total State Budget (APBN). Likewise, the regional government, especially the Government of Aceh, each year sets a budget not only for formal education but also for non-formal education such as prayer hall and pesantren.

\subsection{Educational Concepts and Infrastructure}

One of the standards regulated in Government Regulation Number 19 of 2005 concerning National Education Standards is the Education Facility and Infrastructure Standards set out in Chapter VII Article 42 that:

1. Each education unit must have facilities that include: furniture, educational equipment, educational media, books, and other learning resources, consumables, and other equipment needed to support a regular and sustainable learning process.

2. Each education unit is obliged to have infrastructure which includes: land, classroom, leadership room of education unit, educator room, administration room, library room, laboratory room, workshop room, production unit room, canteen room, power installation and services, a gym, a place of worship, a place to play, a place of recreation, and other spaces/places needed to support an orderly and sustainable learning process.

The implementation of the SNP above, is regulated in the Minister of National Education Regulation No. 24 of 2007 concerning Standards of Facilities and Infrastructure for Primary Schools/Madrasah Ibtidaiyah (SD/MI), Junior High Schools/Madrasah Tsanawiyah (SMP/MTs), and High Schools/Madrasah Aliyah (SMA/MA). These facilities and infrastructure standards include:

1. Minimum criteria for facilities consisting of furniture, educational equipment, educational media, books, and other learning resources, information and communication technology, and other equipment that must be owned by every school/madrasah.

2. Minimum infrastructure criteria consisting of land, buildings, spaces, and power installations and services that must be owned by each school/madrasah. 
Educational infrastructure is a facility that indirectly supports the course of the education process, such as yard, garden or school park, the road to school, school discipline, and so on.

\subsection{Quality of Education}

The agreement on the concept of quality is returned to the reference formulation or references, such as education policy, teaching-learning process, curriculum, facilities and infrastructure, learning facilities and education personnel in accordance with the agreement of the parties concerned.

Another view states that quality has two different concepts between absolute and relative concepts. In the absolute concept, an item is called a quality when it meets the highest and perfect standards. Whereas in the world of education the concept of absolute quality is elitist because only a few educational institutions will be able to offer high quality to students and only a few students are able to achieve it.

In a relative concept, quality is not an attribute of a product or service. Something is said to be quality if the goods or services meet the specified specifications. Therefore, quality is not an end goal, but as a benchmark for the final product of the specified standard. Quality definition, in relative concept, has two concepts, namely: (1) seen from the point of view of the producer, the quality is to measure based on the specifications specified, and (2) from the customer's point of view the quality meets the demands of the customer.

In the field of education, only relative concepts are often found. In this concept, the quality of education is usually measured in terms of its customers, both internal and external customers. Internal customers, namely principals, teachers, and other education staff. According to Sallis [8] to see quality from an external customer point of view there are three groups, namely: (1) students (primary external customers), (2) parents and government leaders (secondary external customers), and (3) markets work, government and the wider community (tertiary external customers).

The quality of education is not only determined by the school as an educational institution, but it is also still adjusted to the views and expectations of the people who tend to always develop along with the progress of the times. In connection with this problem, Sagala [9] suggests that successful schools are determined by the following factors: (1) teaching and learning activities, (2) the competence of teachers and education personnel to be improved, (3) learning facilities and equipment prepared, and (4) extracurricular activities.

Furthermore, Sagala [9] makes indicators of success in improving the quality of education will have an impact from various aspects, namely: (1) The effectiveness of the learning process is not just the transfer of knowledge, but rather emphasizes internalization developing cognitive, affective and psychomotor aspects and independence, $(2)$ the leadership of the principal will encourage the realization of the vision, mission, target objectives through programs implemented in a planned, gradual, creative, innovative, effective, have managerial ability, (3) management of effective education personnel, (4) schools have a quality culture, (5) schools have a compact, smart and dynamic teamwork. Because education output is a collective outcome, not individual results in order to obtain competitive quality, (6) schools have independence, namely: the ability to work optimally by not being dependent on instructions from superiors and having potential human resources, (7) participation of school citizens and society. Linkages and involvement in schools must be high based on a sense of responsibility through loyalty and dedication as stakeholders, (8) schools have transparency, (9) schools have the will to change (management change). Change is an increase in positive meaning for better in improving the quality of education, (10) schools carry out continuous improvement evaluations and are an improvement process in improving overall quality, including organization, responsibility, 
procedures and human resources, (11) schools have accountability as responsibility for the success of the school program that has been implemented, and (12) the school's output is emphasized to graduates who are independent and fulfill job requirements (qualified).

The quality of education must be strived to achieve progress based on a planned change. Improving the quality of education is obtained through two strategies, namely: (1) improving the quality of education that is academically oriented to provide a minimal basis in the journey that must be taken to achieve the quality of education required by the demands of the times, and (2) improving the quality of education oriented to essential life skills covered by broad, real and meaningful education. In relation to the strategy to be pursued, improving the quality of education is closely related to the relevance of education and assessment based on the actual conditions of the quality of education. The study of the actual situation is the starting point in traveling to an ideal situation which is preceded by a threshold as a minimum foundation and includes the quality of education that is accountable and which is marked by a benchmark as normal ideal.

The quality of education is not only determined by the school as a teaching institution but also adapted to what is the view and hope of the people who tend to always develop with the progress of the times. Based on this tendency, the community's assessment of the quality of school graduates continues to develop.

\section{Method}

This study uses the descriptive method with a qualitative approach. The use of this method is based on the research objectives that have been formulated, namely describing and analyzing the Effectiveness of the Management of Financing and Education facilities on the Quality of Education in Yapena Private Madrasas in Lhokseumawe City. Research subjects included Madrasah Heads, deputy heads of madrasah in the field of facilities, madrasah committees, Yapena madrasa management foundation, and parents of students. The research instrument used in this study is the interview guide to the research subjects. To maintain the validity of the data obtained by testing the credibility of the research data in accordance with the procedures in qualitative research. Sugiyono [10] said that "the data credibility test or the confidence in the results of qualitative research, among others, is done by extension of observation time, perseverance in research, triangulation and using reference material". Data collection techniques used in this study are interviews [10], observation, and documentation [11] The three methods are expected to complement each other so that the expected information is obtained. Data analysis uses the Miles and Huberman [10] stage that activities in data analysis are: Data reduction, which is summarizing, choosing key things, focusing on important things and removing unnecessary things. Thus the data that has been reduced will give a clearer picture. Presentation of data, which presents a set of information that is arranged which gives the possibility of drawing conclusions and taking action. Conclusions are drawn, namely, conclusions are made so that the data that has been analyzed and given interpretation or interpretation has meaning to then be compiled into descriptive sentences that can be understood by others and can inform about the results of the research. 


\section{Result and Discussion}

\subsection{Management of Education Costs and Facilities in Yapena Private Madrasah in Lhokseumawe City}

Planning for the management of education costs and facilities in the form of the preparation of the Madrasah Revenue and Expenditure Budget Plan (RAPBM), held every year before the start of the education process at the Yapena Madrasah in Lhokseumawe city. The head of the madrasah actively participates in the madrasa deputy heads, committees, and the teachers compile the plan. Because this is a private madrasa, the Foundation also actively composes plans for managing education costs and facilities for the next year. The reference used is the vision and mission contained in the Yapena madrasa Strategic Plan.

Yapena Madrasah composes a number of madrasa activities that can be divided into madrasa activities that are directly related to students and other madrasah activities, such as madrasah formation which includes curriculum development, supervision, rakerdin, mentoring madrasah heads, teachers, and madrasa operational activities. In the RAPBM, it was also determined who was assigned to manage the cost of education in the madrasa, namely the treasurer as the manager of fees and the head of the madrasah as the management supervisor carried out by the treasurer. While to help the treasurer for certain matters a special team was formed.

If in the implementation of the cost there is a change in the implementation of the budget or work program, then the head of the madrasah immediately takes the policy and announces it to all interested parties by stating the reason for the changes implemented. As responsibility for the implementation of the management of education costs in madrasas, the treasurer is obliged to make daily, monthly and annual financial reports. The report made by the treasurer uses standard rules and is also used by the head of the madrasah as a supervision of the use of education costs.

\subsection{Effectiveness of Management of Costs and Facilities to Improve the Quality of Education in Yapena Private Madrasah in Lhokseumawe city}

In terms of input, management of education costs can be viewed from the suitability of work programs with the needs of madrasas and the acceptance of sources of financing for madrasas. If viewed from the suitability of the program or plan with the needs of the madrasah, then the management of education costs and facilities can be said to be effective because the programming (RAPBM) has been adjusted to the curriculum and needs of madrasas. Meanwhile, when viewed from the point of view of receipt of madrasah income sources, the management of education costs and facilities is still ineffective because the sources of income are less able to achieve the expected targets and are not received according to the planned time.

In terms of the process of managing education costs and facilities, it is also less effective, this is because in its implementation there is still overlapping management even though assignments and responsibilities for carrying out these activities have been determined in advance. Meanwhile, in overcoming the changes that occur can be said to be effective because it does not require a significant overhaul in the implementation of the cost plan and educational facilities.

In terms of output, management of education costs and facilities can be seen from several things, namely, reporting time, costs for managing costs and facilities, as well as the quality of the information provided. In terms of reporting time, it can be said that the management of education costs and facilities is quite effective because timely reporting and costs for managing education costs and facilities are relatively cheap. Whereas when viewed from the quality of the 
information provided, the management of education costs and facilities can be said to be less effective, because of the lack of transparency in the financial statements. The indicator can be seen from the less reported as a whole per budget line for each financing plan that has been prepared.

\subsection{Constraints in the Management of Education Costs and Facilities in Yapena Private Madrasas in Lhokseumawe City}

In managing the costs and means of education in the Yapena Madrasah, the city of Lhokseumawe, several problems were encountered, first, the funding sources (SPP) that were not timely. Delays in obtaining costs are serious because the inconsistency in the cost of education will affect the effectiveness of financing and other academic activities. This phenomenon will have an impact on improving the quality of education.

\section{Conclusions and Recommendations}

\subsection{Conclusion}

1. Management of education costs and facilities at Yapena Madrasah in Lhokseumawe city can be grouped into three stages, namely planning, implementing and evaluating.

2. Management of education costs and facilities in Yapena Madrasah in Lhokseumawe city is not fully effective, this is seen from the point of input, process, and output of the management of education costs.

3. In managing education costs and facilities, problems are encountered, namely Madrasah income (SPP) which is often late for students to pay.

\subsection{Suggestion}

The results of this study gave birth to the following suggestions:

1. For the head of the Yapena Madrasah, to further maximize funding sources, it is necessary to further activate the role of the committee since the preparation of the Yapena Madrasah RAPBM to help find financing for Madrasas.

2. The government should be more active in providing socialization on the management of costs and educational facilities to be more effective in supporting efforts to improve the quality of education.

\section{REFERENCES}

[1] S. Minarti, Manajemen sekolah: Mengelola lembaga pendidikan independen. Yogyakarta: AR-Ruzz Media, 2011.

[2] Marno and T. Supriyatno, Manajemen dan kepemimpinan pendidikan Islam. Bandung: Refika Aditama, 2009.

[3] N. Fattah, Konsep manajemen berbasis sekolah (MBS) dan dewan sekolah. Bandung: Pustaka Bai Quraisy, 2007.

[4] D. Suhardan, Riduwan, and Enas, Ekonomi dan pembiayaan pendidikan. Bandung: Alfabeta, 2012.

[5] Jafar, D. AR, and Khairuddin, "Manajemen pendidikan dayah nurul kecamatan peudada kabupaten Bireuen,” J. Adm. Pendidik. Pascasarj. Univ. Syiah Kuala, vol. 4, no. 1, pp. 56-62, 2016. 
[6] M. I. Anwar, Administrasi pendidikan dan manajemen biaya pendidikan. Bandung: Alfabeta, 2004.

[7] B. Suryosubroto, Manajemen pendidikan di sekolah. Jakarta: PT Rineka Cipta, 2004.

[8] E. Sallis, Total quality management in education (Terjemahan: Ahmad Ali Riyadi dan Fahrurrozi. Yogyakarta: IRCiSoD, 2006.

[9] S. Sagala, Kemampuan profesional guru dan tenaga kependidikan. Bandung: Alfabeta, 2011.

[10] Sugiyono, Metode Penelitian Manajemen. Bandung: Alfabeta, 2015.

[11] S. Arikunto, Prosedur penelitian: Suatu pendekatan praktik, Revisi VII. Jakarta: PT. Rineka Cipta, 2011. 